\title{
Miradas fragmentarias: sobre los desnudos en la obra fotográfica de Norma Patiño
}

Raymundo Mier

Universidad Autónoma Metropolitana-Xochimilco / México 


\section{Resumen}

Este texto (en realidad un conjunto de breves textos) pretende una aproximación a las fotografías de Norma Patiño a partir de la conjunción de tres puntos de vista: una reflexión sobre el objeto y el acto fotográficos, una reflexión sobre la condición significativa de mirada y sus límites en la aprehensión del cuerpo con el espectro de sus sentidos, y una reflexión sobre los sentidos de la experiencia corporal y la desnudez en el dominio del erotismo. Las diversas series fotográficas de Norma Patiño, que exploran por distintas vías estas tres esferas de la significación del cuerpo y la fuerza icónica de imagen fotográfica, emplean y recrean una vastedad de recursos estéticos en la tradición los desnudos fotográficos, pero también hacen visibles sus límites, sus fracturas, hace patente las tensiones a la deriva en la aprehensión de la corporalidad y en las aporías de la representación del cuerpo y del juego de la transgresión.

\section{Palavras-chave}

Norma Patiño, fotografía, corporalidad

\section{Abstract}

This text (in fact a collection of brief texts) suggests an approach to Norma Patiño's photographs from the conjunction of three analytical points of view: a reflection on the photographic act and its object, a reflection on the meaningful condition of the gaze and the limits of its possibility to grasp the wholeness of the body together with the spectra of its senses, and a reflection on the corporal experience and the nudity in the domains of eroticism. The different photographic series of Norma Patiño, that explores through dissimilar means this three spheres of the body's signification and the iconic force of the photographic image, use and recreate a vast repertory of esthetical resources from the tradition of the photographic nude, yet they bring to light its limits, its fractures, they stress the evidence of the drifting tensions in the apprehension of corporality, and in the paradoxes of the representation of the body and of the transgression as play.

\section{Key words}

Norma Patiño, photography, corporality 


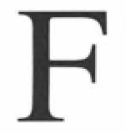

otografías de los cuerpos desnudos sugieren el vértigo y las vicisitudes del asedio: mirar la fragilidad, violentar el resguardo de las identidades, construir la algarabía de una mirada anóima en el cuerpo liberado abruptamente a su propia fascinación, a las sensaciones abismales de otra presencia. Desde su origen mismo, la fotografía asumió la búsqueda del retrato como la tentativa de la captura. El retratista se agazapa. Sigue con la mirada, anticipa, cierra el camino a la disgregación de los gestos, hace que todo el juego de tensiones a la deriva se convierta en la espera recíproca el fotógrafo y su objeto- de la elocuencia mecánica cifrada en el dispositivo óptico de la cámara. La foto surge como el desenlace de un largo acecho, inscribe las huellas de la momentánea de las almas. El desnudo sumó a este acecho, que compartió con la pintura durante los largos debates polémicos del siglo XIX, otra intensidad, la de la transmutación de lo íntimo en una visibilidad anónima, la de la transformación de lo íntimo, lo señalado por el nombre propio, inalienable, en el sustento de un anclaje para la mirada pública. La imagen se convirtió en el lugar de la metamorfosis de las identidades: la vacuidad de las identidades, tomó el anonimato del deseo, jugó con él, lo hizo al mismo tiempo objeto de contemplación y de espectáculo. Con la fotografía de desnudos, la mirada se entrega a una espera y un impulso de captura no sólo del cuerpo sino también del resplandor de los límites, de las calidades de la tolerancia: la fotografía es un acontecimiento que iba más allá del cuerpo para desplegarse en el deseo, en la voluntad de fusión, en el estremecimiento, en la transfiguración de los signos de la hospitalidad, en la exaltación de la disponibilidad, o en la trama del repudio o el estigma.

Mirar los cuerpos fotografiados es precipitarse en la contemplación de cuerpos enteramente plegados a su propia 


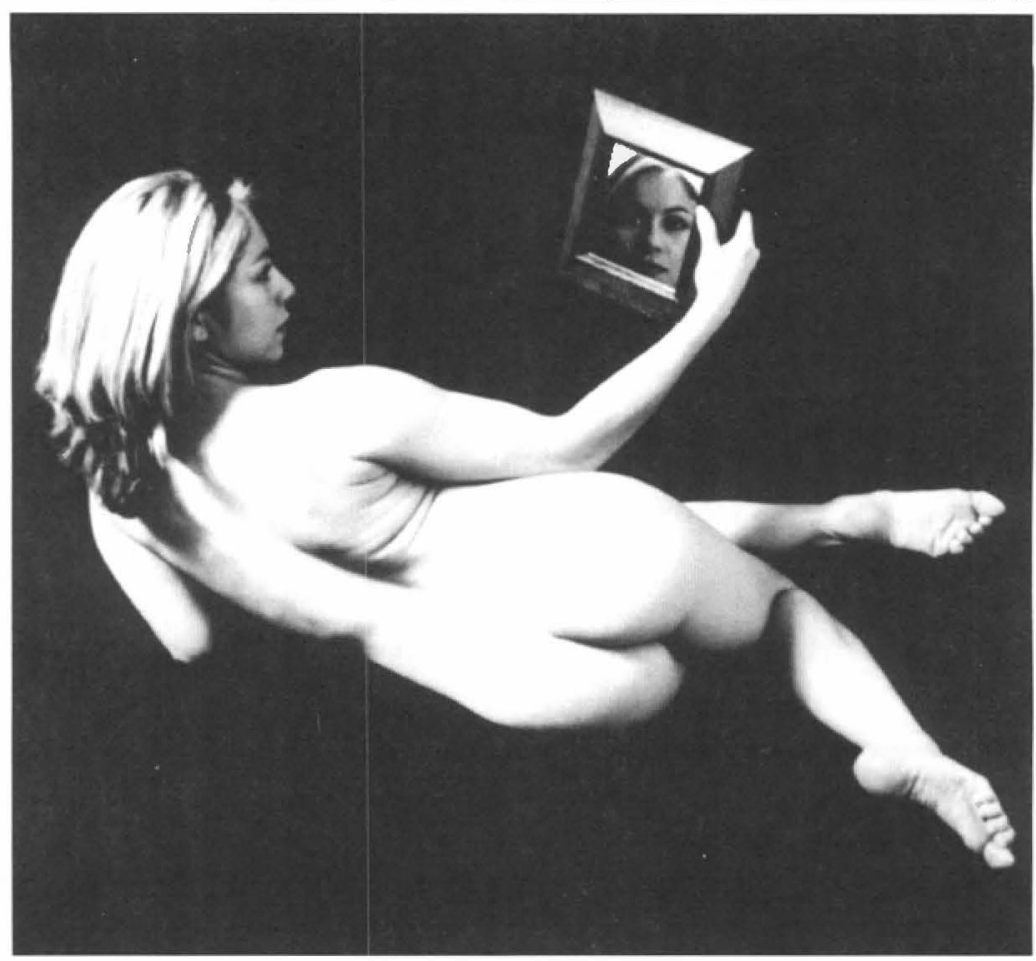

singularidad. Son cuerpos cuyo nombre propio no se despliega en el lenguaje sino en los pliegues, en las tensiones, en su despliegue ante los tiempos y las exigencias de la memoria y la mirada fotográficas. La tensión de los cuerpos habla inequívocamente del tiempo: dice siempre la espera y la promesa, pero también revela la inminencia, lo impostergable o los lapsos de una distensión que revelan la vuelta del cuerpo sobre sí mismo, un recogimiento, una retorno del cuerpo a una imaginación íntima de su propia historia o de los linderos de su delirio. La fotografía revela una faceta singular del vínculo recíproco entre el ojo y el cuerpo, entre los cauces mecánicos de la mirada y la docilidad del cuerpo ante su devenir imagen: es en ese vínculo en el que se engendra el impulso creador, aunque informulable, que sobrepasa la fragilidad del cuerpo desnudo lo dota de una fuerza envolvente que lleva a la mirada a inventar el nombre recíproco de las identidades. Ambas - la mirada y el cuerpo fotografiado- 
experimentan una metamorfosis que se propagara a todas las miradas. Cada cuerpo y cada mirada adquieren nombres tácitos pero singulares, irreparables, llevan el nombre de su propia historia silenciosamente inscrita en el tiempo de la contemplación. La imagen fotográfica preserva esta imagen de los cuerpos, hace de ella la materia intersticial que conjuga la desaparición y la presencia del otro, que se inscribe entre el fulgor del deseo y la indiferencia del lastre orgánico del desempeño cotidiano, entre la huella y la memoria del tacto, de la ternura, de la separación y sus sombras asumidas como el régimen de la propia voz.

La fotografía acoge a los cuerpos en su espacio y su tiempo propios; ahí la mirada se bifurca: dos experiencias del mirar coexisten más allá de toda posibilidad de simetría o concordancia. No hay correspondencia entre el ojo que captura a través de los dispositivos ópticos y mecánicos, que se confunde con ellos y se modela según la particular aprehensión de las imágenes, y el ojo que demora y se fija en la imagen ya fraguada, que se ampara en el detalle y da un destino a los trayectos a la deriva de la mirada que se adentra en la zona áspera del detalle. Estas dos miradas no se distinguen sólo por sus duraciones inconmensurables, sino porque comprometen experiencias que dan a esas imágenes sentidos incomparables. La mirada que fotografía se encuentra con los cuerpos vivos cuya identidad es dehiscente, atestigua la sucesión continua de las facetas de su transfiguración, se ve sumergida en el decaimiento de su efigie, en su desplazamiento que culminará en la desolación fija, inaudita de la pose. Incluso la memoria que aviva la mirada revela en la imagen ya impresa una dualidad insuperable: no hay posible coincidencia entre la memoria del acto fotográfico y la reminiscencia que la composición suscita, cuando ha sido ya transformada en objeto de contemplación. La fotografía es la invención de un territorio etéreo, espectral de los encuentros y su desaliento en las figuras elusivas de la reminiscencia. No hay significado unívoco de ningún cuerpo fotografiado: la incertidumbre del cuerpo se multiplica y se refracta monstruosamente en la incertidumbre de la imagen. Las significaciones moduladas de las intensidades corporales, al fijarse en una imagen fragmentaria se convierten en sentidos que se precipitan en la fotografía para exhibir 
en la imagen el espectro de potencias; esas significaciones señalan sólo el devenir posible de la imaginación de los cuerpos, de su sonoridad inaudible y de las categorías tácitas de la experiencia táctil. No sólo la imagen de los cuerpos se refracta, el sentido mismo de la mirada experimenta la posibilidad de infinitos trayectos arborescentes: la presencia de los cuerpos se fisura al fundirse con la memoria de otros cuerpos, de otras imágenes del cuerpo, con la memoria de las propias sensaciones, con la experiencia de los vínculos y la evocación de sus historias. El cuerpo no es un objeto cualquiera, su fragmentación, su disgregación hace posible la síntesis inacabada, infatigable de la experiencia completa de sí, que se agolpa en los difusos archipiélagos de la mirada. El cuerpo fotografiado no es una imagen sino un punto de bifurcación para el sentido: su resonancia muta, se distorsiona, se disuelve y resurge en una mimesis siempre truncada. El cuerpo no es sino su propia constelación de resonancias, de extrañezas o de figuras conjeturales que se engendran en la historia y la espera de la mirada. Así, cada mirada que se asoma a la imagen fotográfica experimenta su propio desdoblamiento, el tejido de sus propios impulsos obedece a exigencias discordantes de la memoria, del deseo, de la postergación o de la espera de otro cuerpo, de otra proximidad, de otros gestos.

La fotografía - se ha dicho hasta la extenuación- no es sino la huella de la visibilidad de los cuerpos, de su estela lumínica, es su halo residual al mismo tiempo negativo y consustancial: la huella conjuga en el impulso de su trazo el testimonio de la existencia del cuerpo y la negación de ese cuerpo. La fotografía afirma simultáneamente la evidencia incontrovertible de su "haber sido" y la extinción de su identidad, eventualmente, su ausencia. La imagen niega radicalmente el objeto que la engendró: no hay posibilidad alguna de derivar de la naturaleza de la huella los rasgos existenciales de su objeto, sólo una vaga sombra precaria y parcial de su materia y de su inflexión dinámica.

No obstante, no hay servidumbre de la fotografía a su objeto. La imagen troquelada en el papel es al mismo tiempo un residuo y una creación, es una figura cifrada que apela a la experiencia del otro, es un despliegue de índices alimentados por un estremecimiento 
irrecuperable, ilegible, y también un signo que rechaza toda voluntad de ocultamiento, de secreto. El desnudo fotográfico no puede ser sino la invención de una figura singular que rechaza toda repetición, toda semejanza con otro y, al mismo tiempo, que entrega el cuerpo como un objeto, como una materia anónima y habitual, carne

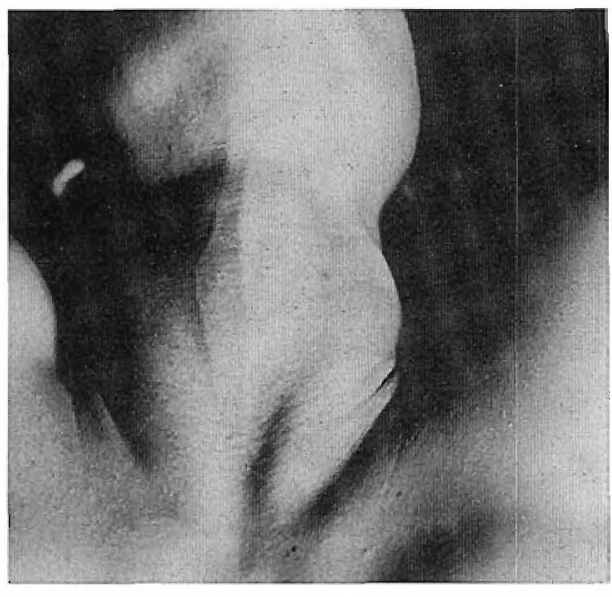
generalizable. Su fisonomía segmentada revela una experiencia de la propia identidad arrebatado por su propia anomalía, en el régimen equívoco que funde en una misma imagen la transgresión y la naturalidad, la forma culminante del deseo y la indiferencia del instinto. La huella fotográfica de esos otros cuerpos desnudos — sus imágenes - arrastra también la mirada a la extrañeza de sí misma. Después de la confrontación con las fisonomías caleidoscópicas de la desnudez, la mirada no puede sino dar cabida a su propia historia, sólo para encontrar su propia vacilación, el vacío de su propia identidad. Es un repliegue, la experiencia de un retorno primordial a sus fundamentos; la mirada se vuelve sobre sí misma para recobrar de esa catástrofe de su propia historia, de su propia identidad devastada por la imagen vacía de esos cuerpos, solo el asombro de su propio estremecimiento ante la imagen anónima, inagotable de los cuerpos.

Las figuras capturadas en las fotografías de Norma Patiño, series disyuntivas de imágenes: cuerpos fragmentados, texturas o pliegues de vitalidad indecidible construidos con la proximidad monstruosa de la mirada, o bien cuerpos irreconocibles trenzados en nudos inextricables y cuyos rostros velados por otros rostros, segmentados, sumergidos en claroscuros exhiben la imaginación inerte de los cadáveres, o bien, segmentos corporales entregados a una sintaxis abierta, o bien escenificaciones oníricas entre dispositivos especulares; un abanico de trayectorias fantasmales de la mirada entregada a 
la exploración de la significación de los cuerpos como el rasgo extremo de lo posible. Esas imágenes son también pactos. Ofrecen a la percepción un conjunto de atmósferas que se conjugan y se excluyen, se interfieren y se dislocan, se amplifican o se profundizan en su diálogo: transitan del claroscuro, las formas canónicas del blanco y negro, hasta la artificialidad de ráfagas cromáticas proyectadas sobre los cuerpos en intemperies inadmisibles. Pero aparecen también cuerpos enlazados en una alegoría de naturalidad; cuerpos anudados bajo el simulacro de una cúpula celeste; formas quebrantadas y sin rostro y señaladas por trazos y fetiches; contornos apenas discernibles que emergen de las riveras ínfimas de sombras tajantes. Pero hay un punto de convergencia en esas series: en todas ellas, el rostro es un vértice engañoso. En las fotos de Norma Patiño ese vértice ha sido suprimido, cercenado; excluido de la fotografía, el rostro engendra un movimiento de síntesis, inscribe el centro de la significación fotográfica más allá de los márgenes de lo visible. La identidad de los cuerpos se proyecta desde ese centro externo como una sombra de la identidad y de la coherencia imaginaria de las significaciones visuales. Ese centro extrínseco, perdido, libera de toda convergencia las exigencias de la memoria, las búsquedas, los reclamos de un deseo que busca cancelar los vértigos del tiempo. No obstante, este centro virtual ahonda la diversidad disyuntiva de las series. Así, en todas las vertientes de las series fotográficas, la mirada y su objeto siguen vías disyuntivas, ajenas entre sí, incluso, a veces, antagónicas. Esas múltiples series fotográficas de Norma Patiño permiten vislumbrar en el espacio fotográfico distancias, proximidades y alejamientos que se desplazan, se suceden, dialogan entre sí para desbordar, miradas en conjunto, una mirada fija, un régimen escénico para los cuerpos. El foco, la intensidad de esas presencias parece moverse al filo de los cuerpos espectrales. Pero la imagen fotográfica no rechaza el vértigo de la extinción: esas efigies de cuerpos no son ajenas a la celebración de la mortandad, a los rituales del abandono, a la exploración de la esterilidad de las imágenes y la laxitud baldía de los cuerpos. La imagen explora entonces la presentación de la vida residual, la muestra de un paroxismo crispado en los cuerpos. Imágenes siempre en los límites de su propia identidad, en los filos de la transgresión. 
Rostros ausentes, quebrantados, velados. Rostros que son sólo la evocación de un resplandor desplazado. Un centro silencioso, imaginado más allá de la imagen misma. El resplandor del rostro es el de su significación al mismo tiempo elocuente, fascinante, seductora, pero también impenetrable y equívoca. El rostro exhibe la dualidad ambigua de una desnudez desmentida y desplegada. El rostro es la afirmación radical de la desnudez y su negación absoluta. Cuando la desnudez del rostro es objeto de prohibición hay siempre una fractura, una reticencia: los ojos, la mirada escapa ineludiblemente a ese velo. Cuando el rostro cae bajo la ley absoluta e inapelable de la ocultación, cuando se lo recluye en el secreto total, cuando se proscribe incluso la mirada, es cuando se lleva al paroxismo la experiencia de la violencia, la supresión mișma del sujeto. La exclusión del rostro es la posibilidad de vislumbrar la muerte en el cuerpo aún vivo del otro. Walter Benjamin había señalado ya el sentido plural de las representaciones del rostro: último reducto de las certezas de la expresividad, epifanía de las identidades, materia laberíntica donde se fraguan las ilusiones y la revelación del sentido de la historia, de su desenlace dramático. El rostro es la superficie expresiva al mismo tiempo inquieta, inasible y sagrada donde aparece el resplandor de la verdad del sujeto, de la especie, del destino, de la redención. Lugar que da cabida a la iluminación incalificable de la mirada, como eje de los extravíos de una imaginación exiliada en la nostalgia de la identidad. La imagen pictórica, señala Benjamin, y luego, de manera sucedánea, la fotografía heredan y preservan esta gravitación de la mirada, esta exigencia de la elucidación del tiempo, este reclamo del escrutinio de las identidades que se precipitan sobre el rostro para revelar en él el sentido catastrófico del destino humano. El rostro es también el lugar del cuerpo donde se decanta el residuo simbólico de una primacía de la contemplación como sustento de la experiencia estética. En el rostro se percibe el juego polifónico de las revelaciones: junto con la identidad contemplada, se revela también la propia, la del pasado que involucra no sólo a un sujeto sino a la colectividad y a la tradición entera. En el rostro se sorprende el sentido radical de la promesa de la historia, que es siempre un juego de utopías y la espera de un advenimiento capaz de engendrar el sentido mismo del tiempo, el tiempo vivido en la 
experiencia propia, pero también el tiempo de lo muertos, de quienes habrán de venir, los ausentes. Pero el sentido del propio rostro no es nunca producto de la propia percepción. No hay rostro ni cuerpo propios: rostro y cuerpo son siempre ajenos, impenetrable para nosotros mismos - esto es ya un lugar común- pero también significado enteramente por los otros. El cuerpo es un objeto enteramente destinado a la donación. El cuerpo - y en particular el resplandor incalificable del rostro- no evoca solamente el reclamo del vínculo, la exigencia de una alianza, el germen de la congregación, la fuerza ritual de la promesa y de la espera. Asimilar el sentido del cuerpo, aprehender la calidad de su deseo, es en principio mirar el rostro, mirar la mirada del otro, recobrar de esa mirada el contorno de la propia identidad. Cuando la efigie del cuerpo ha sido privada de su rostro hace patente una fractura en el horizonte de la mirada, hace vacilar el sentido de esas intensidades hechas visibles por la mera disposición de los torsos, los muslos, los brazos, los cuellos. Un cuerpo privado de rostro es una figura abandonada al vacio de su propia historia, abierto a una intemporalidad que emerge desde la catástrofe de la expresividad. Arrancado del rostro, el cuerpo parece entregado a todas las posibilidades, aparece arrastrado a una disponibilidad absoluta. Su ingreso en la fragilidad del sentido. Es la liberación de la historia, la derrota misma de los hábitos, la exclusión de la mirada

Los cuerpos ofrecidos por estas distintas series conllevan tåmbién una incesante transformación de la mirada del observador: no se pueden ver con los mismos ojos, no responden al mismo juego de deseos, no solicitan las mismas complicidades ni revelan significaciones concordantes. Cada serie se interna en territorios discordantes de la mirada, los cuerpos emergen como objetos inertes o como figuras de una escenificación, como espejismos oníricos o pliegues deliberados en la historia misma de la fotografía; evocan citas de Weston o variaciones sobre Newton, derivaciones de Brandt o de Brassaï, juegos de luces solo reconocibles en la estela de Man Ray. Esos cuerpos no sólo sintetizan experiencias, evocaciones, fantasmas, miradas o sensaciones; condensan también diversas síntesis de historias distantes: historias de la mirada y de la imagen, la historia de las técnicas, la historia de las alianzas secretas entre imagen, 
experiencia, narración y cuerpo que han dado forma a la experiencia de la sexualidad en nuestra civilización, historia de la transgresión y el erotismo, historia de los mundos secretos y de las subversiones públicas. Las imágenes transitan de una síntesis a otra, de una memoria a un estremecimiento, de una plena identificación de la mirada en el seno de la historia y la tradición contemporáneas y de su abandono. Estos desnudos son un momento en una herencia displicente de la cultura o integrada tácitamente en una exploración de la singularidad estética de la composición fotográfica. Pareciera que cada serie fotográfica articulara una multiplicidad de voces convergente cuyos juegos luminosos revela historias, sintaxis, hábitos o proclividades que se expresan en modos de composición contrastantes.

Pero sobre todo asume las presencias capaces de dar cuerpo a riesgos y deseos encontrados, irreconocibles, mundos abismales y conjugados en el espacio permeable de los signos. Cada serie delimita una y otra vez territorios, zonas de la experiencia, marcados por distintos desarraigos a partir de los cuales habrán de ofrecerse a la mirada como líneas de fuga de la experiencia erótica. El de Norma Patiño es un erotismo recorrido por el latido sanguíneo de la violencia de la separación; la fotografía inventa para sí misma la fuerza de una mirada que es al mismo tiempo la promesa de la memoria imposible de la fusión de los cuerpos, y el desaliento duradero de la derrota de la propia identidad.
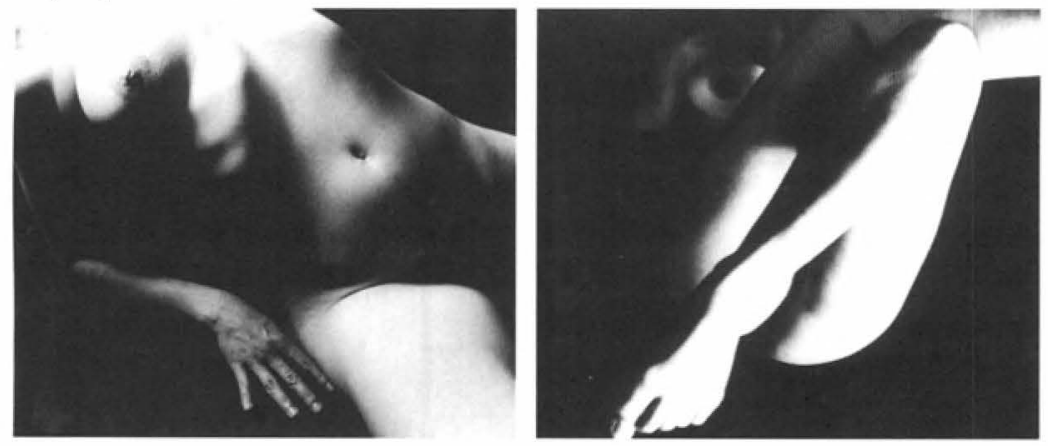

Vuelvo a las fotografías. Miro una y otra vez los cuerpos que reclaman la reiteración agobiante de las miradas. La violencia inerte de toda repetición: volver a las fotografías como a los cuerpos, 
para avivar una fascinación abismal que se arraiga en territorios acotados del propio cuerpo, que se extravía y se asienta en sus pliegues hasta la metamorfosis de las sensaciones, la percepción, la mirada misma. La repetición desertifica los cuerpos, las epidermis que son mimesis de extensiones geológicas, de patrones pétreos. La fotografía de desnudos de Norma Patiño no se rehúsa a explorar la violencia disiuptiva de los cuerpos neutros, las sexualidades baldías, los cuerpos iluminados por una utopía en el filo de la muerte del deseo, en el abismo inerte del objeto; esta fotografía no rechaza el encuentro con los cuerpos como meras emanaciones de la epidermis, como una pura resonancia crepuscular de la mirada: la piel como una mera superficie erosionada por los signos, contaminada por significaciones ajenas; intemperie desierta hecha de la impaciencia de una escritura. Sí, el cuerpo como pura materia de impregnación, que aguarda una inscripción, un velo, una transparencia, una talla, un desgaste o un derrumbe minucioso que anticipa la carne derrotada en su propia materia, silenciada en la trama de su propia sangre.

Otras series ahondan esa exploración de los cuerpos como objetos, pero esta vez como un lugar para albergar la luz o para hacer casi tangible la firmeza y la delimitación de los contornos: los tiempos corporales impregnan esta fotografía como una planicie inerte, cuerpos que parecen ajenos a toda experiencia y por consiguiente a todo sentido, fragmentos de cuerpos erigidos como objetos insensibles a la presencia de la mirada, del otro, de la violenta interpelación de su propia historia. Pero la fotografía de Norma no se agota en esa fascinación mortífera, se abandona también a los impulsos que labran los cuerpos con la avidez de la ficción; escenas que congregan presencias como un deambular onírico de la mirada, capturada entre los cuerpos y sus imágenes especulares. En ese juego onírico, las miradas cobran una fuerza densa de escrutinio, interrogan como una avidez tácita: los objetos fotografiados son menos los cuerpos que la expectativa de ofrecer a la mirada los itinerarios del deseo. Las miradas se reflejan ahora unas en otras: transitan del entorno de la imagen fotográfica a su "interior", se reflejan en los espejos que a su vez figuran cuerpos que a su vez son vértices en los que convergen las miradas. La pasión onírica de estas fotografías estriba en este 
deambular de la mirada en los juegos de la mirada en los objetos de deseo, la mirada se adentra en los cuerpos que se miran, en sus espacios, en sus reflejos. La fotografía y quien la contempla son a su vez figuras que se integran en ese orden onírico, que se integran en ese mundo de figuras que se desdoblan en su propio resplandor especular, para revelar un encuentro que a su vez materializa y desmiente las constelaciones del sueño. Norma Patiño se enfrasca en esa tarea imposible: fotografiar la captura de la mirada, su residencia en los juegos de espejos que se multiplican hasta integrar, en sus facetas cambiantes, a la propia mirada fotográfica, a su dispositivo óptico, a los espectadores intemporales capturados también en esa escenificación.

El entramado de las series de desnudos de Norma Patiño explora el sentido de la transmutación incesante de la proximidad. La fotografía inventa una alianza entre la experiencia de proximidad y la ambigua intimidad de lo insólito, de lo intolerable. La mirada que habita la fotografía señala el lugar inhabitable de un cuerpo; los cuerpos recogidos en la imagen desmienten toda nuestra experiencia del espacio, del tacto, de las texturas, de la consonancia de los latidos; pero esa cercanía figurada cobra otra densidad. La mirada fotográfica parece en un momento emerger como una emanación del cuerpo que posa, arrastrar con ella los rasgos de su intimidad, de su verdad, y, sin embargo, en otra imagen, la mirada fotográfica se distancia de su objeto, asume la lejanía neutra de un relato impersonal, no hace un tú de ese cuerpo que se dibuja en el lente; apunta a él quizás en tercera persona, como un él, o ella, o incluso con la violencia neutra de un ello, un mera opacidad cuya relevancia es resistir, mostrarse indócil a la mirada. Esa fotografía impersonal, en "tercera persona" bien, puede en otro momento invocar la complicidad de la contemplación, del mero registro, del testimonio incólume que se detiene en una huella, en virtud únicamente de la anomalía ínfima del cuerpo. Las fotografías recorren las gamas de la proximidad y la distancia, desde el lenguaje secreto, íntimo, del diálogo yo-tú, hasta la sombra distante del registro: involucran la tensión de la caricia, o se deslizan en el diálogo de voces desde una naturaleza muerta hasta un abrazo íntimo. La fotografía explora en los cuerpos una visibilidad 
que se inscribe entre estos extremos: lo íntimo y lo inerte, construida en la materia ávida de un asombro. La imagen entonces aparece en algunas ocasiones como celebración del encuentro, un descenso a la proximidad extrema, incluso hastá la fusión de identidades, conjugaciones de cuerpos que hacen visible la intensidad, la intimidad como devastación, la forma de tonalidades. Pero en otras ocasiones la imagen se transforma en un informe, en una cartografía de formas sin edad, sin sedimentaciones, sin más misterios que su propia docilidad. Los cuerpos saturan la superficie visible de la fotografía para ofrecerse sólo como soportes de la pasión desdeñada en la fatiga exuberante de los fetiches. Se transita también en las fotografías de Norna Patiño por un espectro de residuos, por el naufragio de reminiscencias que trastoca la obsesión de la fotografía, y la traduce en una promesa tácita, oscura, destinada a un silencio invencible, a un juego abismal de la tragedia de la mirada, a una confrontación con el vacío de cuerpo.

No es posible la percepción del cuerpo como totalidad, y, sin embargo, la experiencia de sí mismo, de la mirada, del sentido mismo del mirar no tienen cabida sin la propensión a esa apuesta por la identidad. Cada fotografía pretende ofrecer el cuerpo pleno, el cuerpo como totalidad en la conjugación secreta de las facetas visibles. Restaurar la experiencia de esa intimidad de los cuerpos a partir de esa percepción parcial hasta lo inadmisible, equívoca, engañosa. La fotografía es fiel a la experiencia habitual de la percepción del cuerpo: nunca hemos mirado la totalidad del cuerpo, ni el propio ni el ajeno, salvo como el producto de una apuesta imaginaria surgida de nuestra propia historia y modelada según la anticipación fantasmal del otro. La percepción fragmentada del cuerpo es algo al mismo tiempo fatal e insostenible: la propia noción de cuerpo reclama la integración, la invención de una totalidad que, no obstante, es asediada una y otra vez por la imaginería obsesionante de su propia disgregación. Es esta imposibilidad de aprehender la totalidad del cuerpo la que hace patente el fracaso de la mirada, su derrota irreparable. Y esta imposibilidad se propaga también al acto fotográfico: el cuerpo se vuelve puramente conjetural, imaginario en sus tajos marginales, en sus cortes, en sus exclusiones, en el acotamiento de sus confines. La 
mirada no puede sino reconocer en el cuerpo el fracaso de toda estrategia perceptiva ajena a los recursos técnicos. La mirada aprehende la totalidad del cuerpo solo a través de recursos parásitos, de juegos suplementarios, accesorios, ajenos al cuerpo mismo. Más que ampliaciones de la potencia corporal, los dispositivos ópticos para aprehender el cuerpo íntegro imponen su lógica, inscriben su propia exigencia, proyectan su propio sentido sobre la imagen. La totalidad del cuerpo surge, en la experiencia fotográfica, necesariamente de un laberinto de artificios. Así, el cuerpo se repliega más allá de la parafernalia tecnológica y preserva su calidad enigmática. Al margen de su imagen, esa oscuridad, esa imagen distorsionada y oblicua preserva en sí mismo su extrañeza. El cuerpo preserva su contorno inaccesible, su naturaleza fragmentaria, secreta, que se expresa una y otra vez en la experiencia: el cuerpo se afirma a través de su negatividad fotográfica como un régimen inexplorado de la sensibilidad, inagotable incluso en los umbrales de su agotamiento, en los bordes de su extinción. La fotografía corrobora la experiencia de lo inhabitable de la verdad del cuerpo, una superficie elusiva, una cavidad sin profundidad, un pliegue infinito de una epidermis inquietante que se vuelve sobre sí misma para producir el simulacro de la profundidad. La experiencia del cuerpo emerge en la figura fotográfica como una efigie desigual de claroscuros delineados por la traza del mutismo, por el enigma. La fotografía captura la condición esencial del cuerpo: una opacidad hecha de una pura superficie, una pura evidencia y como clausura: no hay profundidad del cuerpo, el cuerpo es el lugar de la afección, pero es al mismo tiempo insondable y limitado, cerrado. La experiencia está confinada a esa superficie corporal siempre segmentada aunque difusa en sus contomos. El cuerpo está sacudido, conmovido incesantemente por la marea inextinguible de las percepciones. Son esas sensaciones, la aprehensión de esas sensaciones, las imágenes que suscita, las memorias que se decantan en ella para reaparecer más tarde, lo que constituye el testimonio indescifrable aunque íntimo, irrenunciable, de su propia identidad. El cuerpo carece de otra identidad que la que surge de ese proceso múltiple, labrado en la epidermis misma, y, sin embargo, limitado por el alcance de nuestras sensaciones y la imaginación - reminiscencia, 
atención y anticipación-que éstas alimentan como sustrato de nuestra propia experiencia. El cuerpo aparece así como la fuente y el resultado de la experiencia y su lenguaje elíptico, es la condición de una diseminación desigual e inquieta de silencios. Pero el cuerpo del otro es meramente conjetural: punto de referencia ineludible para la aprehensión del cuerpo propio y, al mismo tiempo, fruto de la imaginación mimética, de las identificaciones mudas, de los asombros truncados. El cuerpo del otro es el ingreso en la trama de la efusión intempestiva de señales opacas, es el reclamo trágico de una derrota incesante de la interpretación, pero también de su exaltación, de su consagración ceremonial. El cuerpo del otro es una efigie cuyo enigma inviste también el cuerpo propio. El cuerpo y la efigie: la contemplación de los cuerpos los torna inauditos, incomparables, irrecuperables en una fragmentación que reclama incesantemente del olvido. Pero los vuelve también familiares, meros ecos de las pasiones habituales. Los cuerpos se vuelven el lugar de la tristeza muda, cotidiana, de los objetos abandonados más allá de la mirada y la conciencia. Mirar esos otros cuerpos, su paso, su acción, su olvido de sí mismos es también construir la identidad como el olvido de la propia finitud de los cuerpos y de su fondo inabordable. Olvidar la fragmentación del cuerpo, inventar una totalidad, cancelar la oscuridad que esa fractura arroja sobre la sensación y sobre el deseo.

La imagen y el cuerpo son irreductibles recíprocamente. Pero la imagen a su vez se desdobla: invención pulsional e investidura modelada por los saberes vigentes. Múltiples imágenes del cuerpo: biológicas, laborales, deseantes; patrones figurativos y lugares de residencia del deseo. Los cuerpos se multiplican en sus imágenes y ofrecen una masa incalculable de efigies sobrepuestas. El cuerpo en su impulso corporal se separa de la constelación de sus efigies. No hay nada en la imagen que recobre la plenitud del cuerpo, y nada hay en el cuerpo que haga posible vislumbrar las potencias desconcertantes de sus imágenes. $Y$, sin embar'go, entre el cuerpo y sus efigies se advierte el vínculo invencible de la analogía. La fotografía asume así, al engendrar imágenes singulares de los cuerpos, dos riesgos igualmente mortíferos: entregarse a la ilusión de la analogía —pensar en la fotografía como icono o como índice-, o bien empeñarse 
en la exhibición de esa discordancia indefectible, intrínseca, pero proclive al extravío, al vértigo: la fotografía no dice del cuerpo sino su evanescencia. Nunca el cuerpo puede sobrevivir a la extinción de su imagen, el derrumbe de su efigie arrastra consigo el sentido de sus evidencias. Tampoco la imagen corporal puede cancelar su lazo primordial con la carne. Pero este lazo es incognoscible, es sólo una conjetura discernible vagamente de los hábitos, de los gestos, de los atavismos, de las reminiscencias que afloran insensiblemente en los párpados, en los músculos, en los esquemas de cada movimiento.
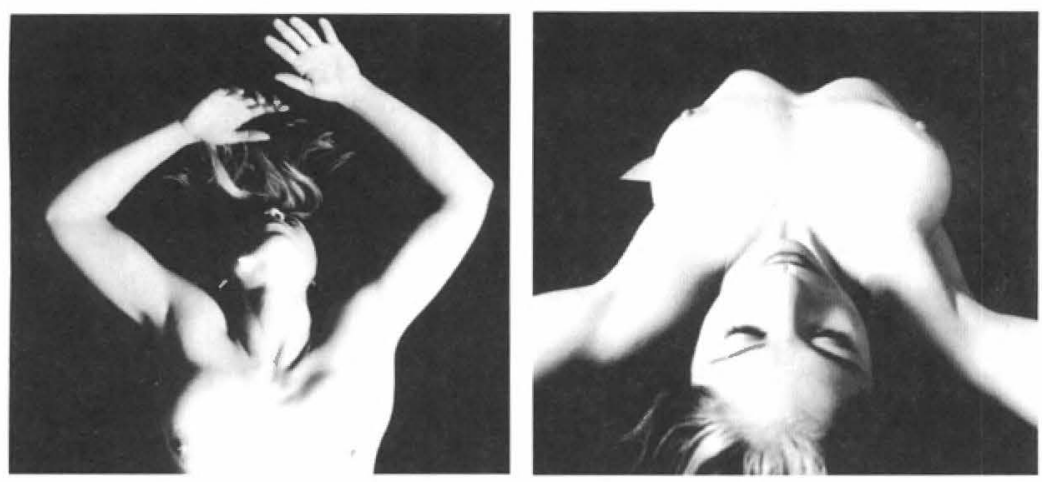

No tenemos palabras para cifrar esta relación desafiante entre el cuerpo y sus efigies. La historia del pensamiento ha acuñado una visión dualista: el cuerpo y el alma, biología y psique, conciencia y fisiología. Ha habido también otras. El dualismo entre cuerpo y alma no es sino otra imagen imperfecta de esta otra discordancia: la del cuerpo y sus efigies. La imperfección negativa de este dualismo ha sido patente y se expresa en la fábula fotográfica. La sombra equívoca de una semejanza es el rostro inextinguible de la elegía de los cuerpos, del duelo, de la pérdida del objeto que es también la pérdida de cualquier aliento duradero de la imagen. Las fotos de Norma Patiño eluden esa trampa incesante de la fotografía: la imagen no recoge analógicamente los cuerpos, el registro fotográfico exhibe esos fragmentos corporales para hacer patente lo irrisorio de los códigos, la traductibilidad de los cuerpos en cifras de sentido. Esas fotos, acaso como las de Weston o las de Mapplethorpe revelan el vacío, la ausencia, la perseverancia imposible del cuerpo que se acuña 
en las placas de esa celebración mortuoria del "nunca más" de lo mirado.

La mirada fotográfica se desdobla en el tiempo, pero también en la memoria y en la relación espectral con el objeto. Si, como podemos desprender de Roland Barthes, el régimen irreductible de sentido en la fotografía apunta al tiempo dual de la presencia del objeto: por una parte, a la calidad ontológica de sus objetos - la fotografía ofrece el testimonio inequívoco de que "eso ha sido"- por la otra, a la calidad enigmática del sentido mismo de la imagen —el sentido de la imagen surge de los trazos mismos de su segmentación, es de la posición de la mirada, del juego de su proximidad, de las exigencias formales de su marco, de donde surge su fuerza y su capacidad indicativa y la calidad de su fidelidad icónica. Así, la imagen fotográfica es el producto de un modo de darse denso del tiempo ontológico de aquello que fue fotografiado. Por el otro, es la revelación de la efigie fotográfica como el producto frágil, precario, de la identidad imposible de la mirada y su propia finitud ahondada por las determinaciones tecnológicas. Más que una réplicá o un registro, la imagen fotográfica es una señal, una metáfora, una afirmación de los horizontes de sentido y una inscripción temporal de la mirada en el espectro de su historia. El "eso", rasgo esencial del acto fotográfico, hace patente el rasgo ontológico imborrable de lo que ha ocurrido. Pero el acto mismo de señalar es inestable, móvil, inquieto, se transforma en las distintas fases que acotan el sentido de la imagen, que enmarcan y sustentan la lectura. Porque el "eso", el gesto con el que la imagen marca sus propias efigies, también adquiere una capacidad de multiplicación y de metamorfosis simultánea: el "eso" - como ha señalado elocuentemente Wittgenstein- librado a su propia fuerza indicativa carece de destino o de objeto propio: puede señalar un objeto cualquiera o alguna de sus calidades, puede señalar el tiempo o las vicisitudes del acontecimiento, puede apuntar a la trama de relaciones, puede acentuar el sentido mismo de la posición y el acto de la mirada. El "eso" no tiene como referencia de la marca existencial solamente el objeto, sino también el ser mismo de la mirada, el espectro complejo de vínculo que involucra no sólo el mundo fotografiado sino la esfera misma del mirar fotográfico. El "eso" 
señala también el sentido del mirar, el encuentro de los signos y los objetos, de los signos y las miradas, subraya la condescendencia de los otros al acto fotográfico o su aquiescencia, hace visible el deseo de fotografía y la voluntad de inventar esa imagen. El "eso" es una caja de resonancias que abre su significado al asombro del advenimiento del objeto fotográfico mismo y de su historia íntima. El "eso" adquiere una fuerza reflexiva, retorna sobre la mirada y la marca, la muestra en su singularidad y quizás, más radicalmente, en su impulso intransferible: lo que vio el fotógrafo jamás será mirado otra vez. No es sólo que esa configuración contingente de objetos, ese acontecimiento no se volverá a repetir, es que esa mirada no volverá a existir investida con ese mismo deseo, esa potencia de aprehensión, esa posibilidad de composición, esa proximidad y esa voluntad de memoria y de imagen. La imagen fotográfica es el aura de esa multiplicidad de apuestas ontológicas que permanece como el sustrato íntimo de la imagen. Así, la traza impresa en la materia fotográfica no es sino un espectro de todos esos rasgos de ser, la fotografía desborda por completo la mera impregnación que da existencia a esos seres y acontecimientos ya disipados. El "eso" es más que una señal, es la síntesis abierta de señales, es la decantación en la efigie de los cuerpos retratados de los tiempos ontológicos de las desapariciones - desaparecen el objeto y el fotógrafo, el acontecimiento fotografiado y el acto fotográfico mismo, la proximidad entre los cuerpos y la proximidad de la mirada, la multiplicidad de deseos y fantasías que se agolpan en los contornos de la imagen. Toda fotografía, al señalar la multiplicidad de esas existencias, se precipita en el juego de lo monstruoso: vistá a la luz del gesto indicativo de la imagen, del "eso" que hace patente, la imagen se proyecta en todas las dimensiones del acontecer como iluminación y como síntesis de la experiencia, es la restauración tecnológica de una epifanía.

Pero el "eso ha sido" de la fotografía no señala sólo la certeza apodíctica de la existencia, sino más todavía los sentidos inextinguibles de sus desapariciones. Las imágenes fotográficas no sólo señalan lo evidente de la existencia de ese cuerpo, sino la fuerza de su disolución: el "eso ha sido" no es menos consustancial a la fotografía que el "nunca más". Cada señal, cada evidencia de lo que 
ha sido, conlleva su contraparte: hace inteligible el duelo, hace patente lo inconmensurable de una repetición infinita de lo que desaparece. Dos regímenes de temporalidad distintos se congregan: la fotografía es la celebración de lo inaudito, lo intempestivo, el milagro de lo que irrumpe por primera y única vez, pero al mismo tiempo la certeza de lo truncado, de lo transitorio, de la primacía de la desaparición. Esta multiplicidad al mismo tiempo memorable y elegíaca de los cuerpos, esta celebración de la experiencia y entramado de las formas del duelo, se exaspera en las fotografías de los cuerpos desnudos, de la misma manera que se revela ahí la atadura densa de los hilos de incontables historias. La imagen es la traza fragmentada de las infinitas miradas ocurridas o por concurrir, de la contemporaneidad de la presencia, de la condición fugaz de las fisonomías, de las expresiones; la precariedad a la deriva de las significaciones, la historia de las distancias y las familiaridades, pero también la historia y los hábitos de la transgresión o la disipación de las identidades.

Los cuerpos desnudos preservan en la fotografía la sombra de esas edades y esas historias incontables, pero introducen un acento adicional: los juegos del deseo y sus límites, de la percepción y sus límites, de la experiencia de fusión y sus límites, de la transgresión y sus límites, las huellas y la visibilidad del placer y sus límites. El espacio fotográfico se puebla de esos acentos, de esas trazas de exclusiones, de censuras, de potencias limítrofes, se proyecta ahí también como un vestigio el testimonio ontológico de la pulsación y la agitación conmovida de los cuerpos. La imagen acoge en su síntesis la evidencia de esas múltiples y anónimas historias desaparecidas a las que se concede el extraño privilegio de una memoria muda y opaca. Los cuerpos son la señal de "eso" que acude a la fotografía como la potencia de un resplandor de la proximidad de los cuerpos. La mirada experimenta entonces un doble movimiento: se precipita en la sombra de esa experiencia o se fija en la materia visible, inerte del trazo fotográfico. La superficie fotográfica se vuelve inerte o bien, se convierte en una iluminación, en un dolor extático, cede su lugar al orden de la ficción, al vértigo narrativo. La imagen de esos cuerpos aparece entonces como emanación de los tiempos dobles de la fantasía: encarnación de los objetos fantasmales, los espectros, las 
zonas intersticiales del deseo destinado al fracaso de la posesión o del contacto con sus propios objetos. La fotografía parece engendrar los cuerpos que ella misma fotografía, para luego acicatear el deseo o ofrecer el testimonio de la vacuidad de sus objetos.

Aprehender el cuerpo fotografiado en el instante mismo de su devenir efigie, monumento. Barthes había advertido ya como la "captura" inherente al acto fotográfico no es sólo el registro del acontecimiento que ha sido, sino también el producto, en quien es fotografiado, de la conciencia - no pocas veces sofocada, aplazada, acallada - de su tránsito hacia la efigie de lo muerto. Muerte y memoria aparecen ya como una revelación. Memoria, muerte: hablan de los tiempos, la duración, el destino de la fotografía. Ser fotografiado para otros o para sí mismo: la fotografía como un don o como una edificación especular. El tiempo de la memoria propia o de la entrega a los otros de los vestigios y los recursos para la invención de una memoria ajena. Pero la memoria del amor tiene otros ecos, es en realidad la reaparición de la memoria y de la muerte como transfiguraciones de la distancia, como la posibilidad de una coexistencia en el ojo de la imagen. Digo "ojo de la imagen" como podría decir "ojo del huracán": punto que es a la vez centro y lugar de extinción del huracán. El erotismo de los cuerpos fotografiados es el "ojo" de esta agitación turbulenta que lleva a los signos de los rituales de muerte a los rituales de olvido, de las narraciones míticas, - los juegos eróticos a los monumentos elegiacos.

En la fotografía, es la efigie del cuerpo del otro y no el cuerpo mismo, perdido para siempre, lo que reclama la devoción de la mirada. La imagen fotográfica es sino un instante de fijeza en la mutación caleidoscópica de una síntesis de efigies. Es esa efigie del otro la que suscita en la fotografía una búsqueda y una reticencia: la exploración del detalle, el escrutinio en busca de la revelación, un impulso de apertura y un recrudecimiento de la reserva: la imagen traiciona siempre, pero también revela y desborda el sentido de lo dado. Preserva el sentido de una identidad pero también impone un peso suplementario a la imagen. El otro adquiere siempre un rasgo de extrañeza: es y no es. El régimen del casi jamás escapa a la fotografía: sola la ilusión del duelo puede cerrar la brecha que nos distancia de la 
experiencia íntima del otro. La imagen es casi el otro. Esa diferencia, esa fisura irreparable entre lo que ha existido y su figura es inherente a la efigie fotográfica. Pero esa fisura se propaga: la imagen fotográfica no alude jamás a la existencia sino al infinito repertorio de efigies que fundan y preceden la imagen fotográfica. La representación es inequívocamente fiel pero inapelablemente perversa en su expresión. No obstante, la imagen exige el olvido de esa fisura, de esa inconsistencia entre la efigie plasmada en la fotografía y la síntesis de las efigies preservadas en la imagen del otro con la que damos forma a la experiencia. Olvidar el casi, transitar entre efigies como si una fuera la emanación de la otra. Transfigurar ese vínculo del casi en un simulacro, en "como si": como si esa imagen fotografiada reflejara el cuerpo, como si ese cuerpo se diera plenamente en su existencia, sin las modulaciones infinitas de la imagen, como si olvidáramos incesantemente esa doble operación de alienación del sentido, ese transformar el "casi" en "como si". La fotografía encubre esa trama de discordancias que aturde la mirada. El "casi" y el "como sî" se funden, ambas operaciones residen secretamente en el desplazamiento y el placer de la mirada, olvidadas, dan forma a una retórica de la memoria. Buscar entonces la compenetración entre la mirada y la efigie, suprimir la fractura, equiparar los tiempos, hacer concordar las identidades. No obstante, esá compenetración entre la efigie y la mirada, ese reclamo de una concordancia recíproca en la posibilidad del encuentro, se exhibe en toda su imposibilidad en las fotos de Norma Patiño. La fotografía suscita una certidumbre: al "eso ha sido" como núcleo de su verdad propia, la imagen añade otra certidumbre: la de la inteligibilidad de las identidades, de las situaciones. La fotografía se ampara en la representación de un acontecimiento inteligible. No obstante, en las fotografías de Norma Patiño la configuración de los cuerpos quebranta la serenidad de las certidumbres. Los cuerpos desplegados han sido privados de la salvaguarda de los simulacros, de las analogías, de las complicidades de la mirada. La mirada se entrega a la contemplación, pero no como un hábito de reconocimiento, sino como una demora en la violencia de la incertidumbre, de esa traza sutil de diferencias que surge de la mirada fantasmal de las cosas. Con frecuencia, en esas fotos la figura de 
ese cuerpo orro es ya incalificable, un giro radical del universo: vacío de rostro, privado de la coartada de la identidad, librado a la expresividad material de su perfil indiferente, satura la imagen con esa presencia expansiva, una oquedad, que se disemina enteramente sobre la fotografía como un vórtice en plena disipación. Ocurre una mutación del sentido: los ojos mudos de quien mira la fotografía encuentran con el silencio de la imagen, suspenden la exigencia del lenguaje, el imperativo del vínculo - abierto o tácito, de las donaciones y el intercambio, de la ternura o la violencia, de la alianza, la desaparición o el sometimiento. La opacidad de los cuerpos no suscita la experiencia de la espera, no hay promesa ni reclamo anudado a la mera aparición de otro cuerpo, de otro rostro.

La desnudez — había sugerido Bataille — es el testimonio de un deseo de soberanía, es la afirmación latente del rechazo de toda identidad, un rechazo surgido no de un arrebato, sino de la experiencia lúcida, deliberada, intolerable del propio derrumbe en la fusión absoluta inherente a la experiencia erótica. No hay genuina desnudez sin la fuerza conmovedora de una iluminación, de una claridad, sin el deseo reflexivo de la propia fragilidad extrema, erigida como gesto radical: la desnudez es una afirmación que pone al cuerpo más allá de todo deseo de expresividad, de toda experiencia determinada, de toda prefiguración de un mundo y de sí mismo. Pero la fotografía es la exasperación de esta soberanía: por una parte, la interfiere al transformar el cuerpo en un objeto ajeno, periférico a la violencia de cualquier prohibición. El cuerpo de la fotografía es anárquico, sin origen, sin identidad, sin el peso de la prohibición, indiferente a la ley. Pero por otra parte, la fotografía exacerba la soberanía, la intensifica al máximo porque multiplica la disponibilidad del cuerpo, lo entrega a una multiplicidad incalculable de sentidos; torna inaprehensibles las identidades que no son ya sino meras potencias de las innombrables miradas que contemplan. La carga erótica de las imágenes surge de la disolución de la identidad como fruto de su multiplicación infinita. Las efigies de cada fotografía se funden entre sí y se confunden con las otras fotografías de la misma serie, las identidades se vuelven una amalgama indiferente que alude a la fusión absoluta, la abolición de todo régimen acotado del vínculo, la exaltación del extravío. No 
hay afirmación de identidad alguna, la fragilidad de la desnudez aparece más como una disponibilidad tácita y como promesa abierta, impronunciada, abierta a las miradas: los cuerpos se transforman en objetos y sujetos de goce, entregados a la extrañeza de sí, a la suspensión de la certeza. Dar cabida en la imagen a la expresión de la experiencia de supremacía es también suspender las facetas del tiempo fotográfico y devolver la primacía a una mirada librada a su propia vocación. La fotografía de los cuerpos desnudos: mirar el tiempo, el cuerpo como advenimiento. Los signos de la promesa insinuados en la sombra de los cuerpos, en la sombra que surge del contacto y que se desliza como un halo en el espectro de la imagen. La imagen como espectro.

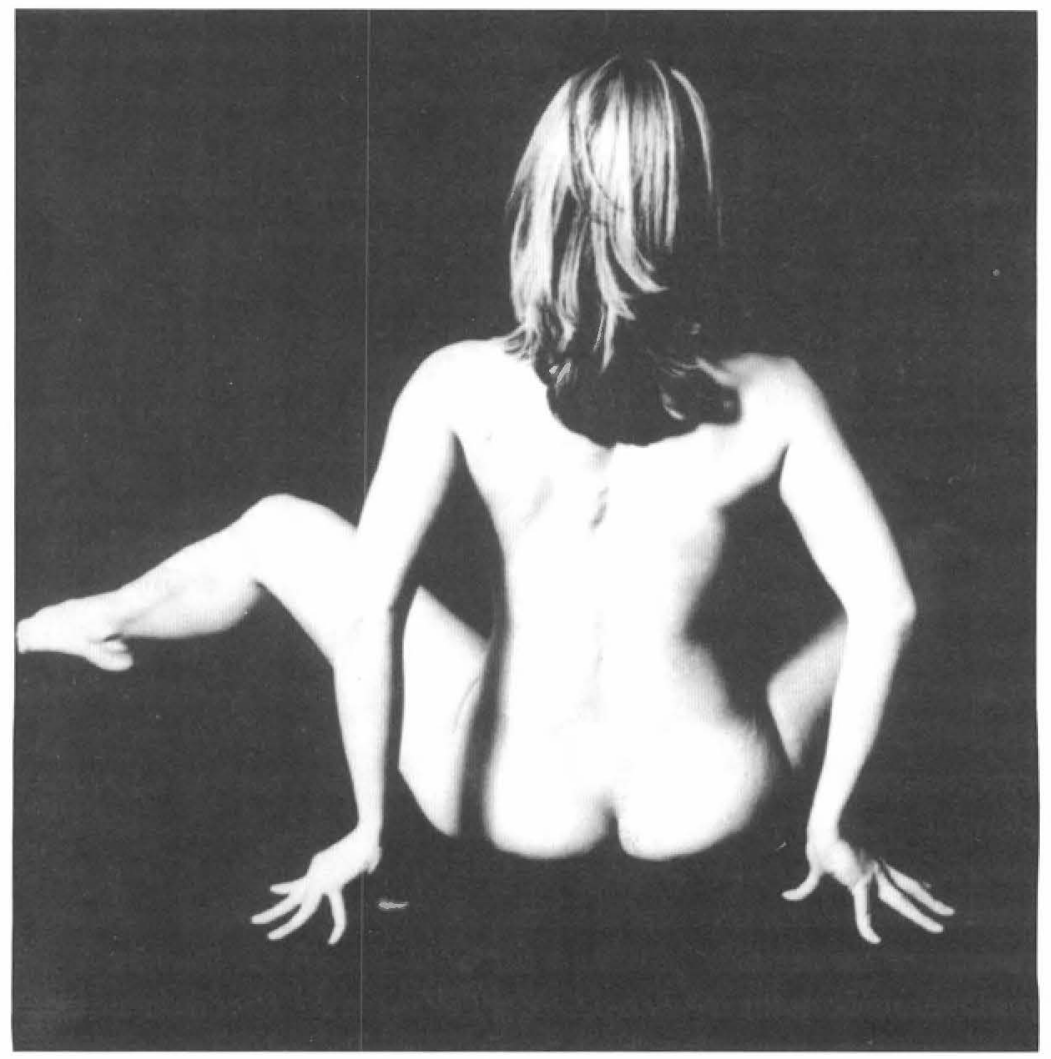


Mirar la desnudez de los cuerpos - los cuerpos en la fragilidad del juego erótico- en la imagen fotográfica suscita el movimiento equívoco y ambivalente de la contemplación: una fijeza incierta de la mirada - mirar la desnudez y no el cuerpo imaginado por la medicina o la biología - que revela o cancela la violencia tajante de la prohibición, pero que alimenta también del recrudecimiento de búsqueda de identificaciones. Es una imagen que se reconoce al mismo tiempo como una incitación incierta, como demanda sin lenguaje, como una exaltación sin objeto. Se trata de una transgresión señalada ya por el relato tácito de la historia. La mirada insiste en su fijeza y, sin embargo, se entrega a la movilización de sus apegos, se repliega a los hábitos de la prohibición - una prohibición que tiene dos rostros extremos, inadmisibles: la desnudez del cuerpo sacrificial, en la intimidad o la proximidad con lo sagrado - intacto e intocable, prohibido no en virtud de su capacidad para suscitar el deseo sino en virtud de su pureza ya inhumana- o bien, el cuerpo material, cuya efigie participa de la indiferencia de la naturaleza y es por consiguiente ajena radicalmente al deseo. Doble régimen de exclusión, de fisonomías limítrofes que llevan la experiencia del cuerpo a su extinción, la colindancia cón la muerte. El cuerpo sacrificial es un cuerpo desarraigado de su mundo, un cuerpo tocado por la monstruosidad de la pureza que lo entrega a la esfera de lo muerto. El cuerpo biológico es un cuerpo imposible, privado de sentido, de finalidad, marcado por el silencio abrupto, irrespirable de la naturaleza. El cuerpo desnudo, en el juego del erotismo, constituye la negación de ambos linderos, aunque preserva el fulgor anticipado de la desaparición: es un cuerpo tocado por la muerte, entregado a una muerte simbólica, a una promesa de identidad y de plenitud. El cuerpo desnudo es ya un cuerpo comprometido en un vínculo arrancado del derrumbe de la muerte, un cuerpo arraigado en una vida intempestiva surgida de los residuos de su propia desaparición.

En una de las series de Norma Patiño, los cuerpos se enlazan, se confunden en un nudo de miembros envolventes, tensos. Su fisonomía se transforma en líneas, tramos rasgados de epidernis de colores contrastantes y volúmenes, en cuerdas musculares, en salientes de carne y miembros apenas reconocibles, en bosquejos de 
rostros cuya singularidad no es diferente del anonimato. Los cuerpos extendidos, enlazados, hacen reconocibles los trazos imposibles del horizonte: la fotografía revela su lugar imposible, las coordenadas vacías de la mirada, la invención radical de confines. Los cuerpos se ofrecen enlazados bajo tonalidades azules, crispadas por jirones de luminosidad que revelan la monstruosidad ficticia del cielo abierto, la línea del horizonte se curva y se quebrantan indóciles, irreconocibles. Es un juego escenográfico del cielo que ampara el entramado impaciente de los cuerpos. Las epidermis contrastantes, entrelazamiento de tensiones, de contactos, de sensaciones adivinadas desde la sombra íntima de la mirada, en un juego de tonalidades que transitan de la palidez sin otros matices que el reflejo inerte del entorno, a los perfiles y las texturas apenas reconocibles en la penumbra densa. Los cuerpos retratados crean una percepción singular del espacio, lo pueblan de esas tonalidades tachoneadas, inauditas. Los cuerpos aparecen como retablos móviles, cromáticos, su espacio y su tiempo son los del vértigo que acompaña a la experiencia del encuentro: esos cuerpos saturan un espacio inhabitable, sugieren un espacio fantasmal, una resonancia plástica, un desplazamiento de los cuerpos a la figuración construida, abstracta, poblada por sensaciones plagadas por la incertidumbre.

Las fotografías de Norma Patiño son, en su variación incesante, una exploración de las gamas dispares de la voluptuosidad. La contemplación de esa desnudez petrificada en la emulsión es también la advertencia de la voluptuosidad como potencia, como fuerza negativa capaz de afirmar el ingreso del cuerpo al rechazo y a la suspensión radical de las certezas. Pero la fotografía es la celebración de esa potencia negativa, una celebración que se expresa en la persistencia de la presencia desmesurada de la identidad del cuerpo investida en deseo, en la duración exorbitante de lá extrañeza de los cuerpos. La fotografía transforma un acontecimiento transitorio - la desnudez y el contacto de los cuerpos, el extravío de la identidad en el erotismo-, en un desconocimiento, en punto de partida de la memoria, en testimonio de un orden exterior a la prohibición edificado en la alianza de la carne y la exploración del placer. La fotografía de estos cuerpos convierte en materia, en objeto, en implantación 
figurativa la evidencia de la experiencia del otro, una experiencia situada más allá de las reglas y la prohibición, una experiencia cuya intensidad surge de la memoria de la propia identidad entregada al pacto de extrañeza con el otro. La fotografía hace de la mirada una capacidad de revocar el olvido que vela la violencia cegadora de la prohibición. La fotografía, al crear para la transgresión una imagen perenne, confiere a esa experiencia del enrarecimiento un tiempo y una duración insospechada. De ahí la persistente perturbación que provocan estas imágenes, su renuencia a integrarse en los hábitos, su tendencia a confundirse con el repertorio de las imágenes familiares. Estos cuerpos poseen una fuerza paradójica: al margen de toda ritualidad, son capaces sin embargo de restaurar el aura de los cuerpos surgido de la fuerza de los vínculos colectivos. Su erotismo no es simplemente producto de una evocación de experiencias vividas, sino de una solicitud cumplida, de una integración viva en el ámbito compartido de la renuncia a la identidad. Juego enrarecido de las complicidades y la invención imaginaria de las atmósferas de la fusión de los cuerpos. La fuerza ritual de la presencia se hace patente, trastoca el anonimato y la materia inerte de las imágenes en signos parciales a través de los cuales es posible entrever esa "otra" ritualidad, colectividad construida ante el deseo en acto, pero alentados por la primacía absoluta del duelo. La desnudez presente en la fotografía cobra la fuerza ritual de una promesa de "redención" (Benjamin) entendida como la renovación de la esperanza de la historia propia y colectiva. Otro mundo se hace visible como un paisaje del tacto y del deseo troquelado en los cuerpos. La fascinación, la repetición absorta de la mirada, el retorno ritual a las efigies, la restauración habitual de ese exilio momentáneo en la densidad pasional de las imágenes es la respuesta a este reclamo de una alianza prefigurada en la composición ritual de los cuerpos. La fotografía de Norma Patiño ahonda la experiencia de esta nueva fundación de la mirada; los cuerpos nos devuelven en esta repetición abstracta a la intensidad pasional de los cuerpos, cada residuo inerte de las presencias anónimas y sin rostro acentúa la multiplicidad del sentido del mirar, su desdoblamiento en un múltiple abanico de resonancias íntimas capaces de engendrar dominios indóciles de la experiencia. 